\title{
COMPARISON OF HOUSEHOLD LEVEL DRINKING WATER TREATMENT TECHNOLOGIES USING ANALYTIC HIERARCHY PROCESS
}

\author{
Deepthi Yaparla \\ Environmental and Water Resources Engineering \\ Civil Engineering Department \\ Indian Institute of Technology Madras \\ Chennai, Tamil Nadu, India \\ E-mail: yaparladeepthi@gmail.com \\ Anand B. Rao \\ Centre for Technology Alternatives for Rural Areas (CTARA) \\ Indian Institute of Technology Bombay (IITB) \\ Mumbai, Maharashtra, India \\ E-mail: a.b.rao@iitb.ac.in \\ Bakul Rao \\ Centre for Technology Alternatives for Rural Areas (CTARA) \\ Indian Institute of Technology Bombay (IITB) \\ Mumbai, Maharashtra, India \\ E-mail: bakulrao@iitb.ac.in
}

\begin{abstract}
Almost 20 percent of the world's population lacks access to safe drinking water (DW) and basic sanitation. The Target 10 of United Nations Millennium Development Goals is "to reduce by half, the proportion of people without sustainable access to safe DW, by 2015". In order to reach the goal, many countries are investing in water treatment systems in a big way. However, it has been proved that household system is more effective than centralized systems as it ensures quality of DW at the point of consumption. The current study compares household level drinking water treatment technologies for urban and rural areas of India using Analytical Hierarchy process (AHP), a multi criteria decision making (MCDM) tool. Traditional and commercial technologies suitable for urban and rural households from the consumer perspective have been considered. Preferences given for the choice of technologies are based on literature review, household level survey, market survey and semi-structured interviews with various governmental and non-governmental officials. The technologies considered for the current study are not only suitable to both urban and rural areas, but affordable (costing up to $` 10,000$ OR \$162) to middle and lower middle class households.
\end{abstract}

The technologies selected include alum, boiling, alum-boiling-straining, SODIS, ceramic candle filters, Biosand filters, Terafil filter, Pure it, Tata Swach, and Aquaguard Compact. Boiling and Aquaguard were top ranked for the urban areas whereas SODIS and boiling were ranked high for the rural areas. The ranking has been found to be sensitive to the attributes such as the initial cost, maintenance cost, durability, reliability and the ability to treat contaminants of the candidate technologies. 
IJAHP Article: Yaparla Rao, Rao, / Comparison of Household Level Drinking Water Treatment Technologies using Analytic Hierarchy Process.

Keywords: DW treatment technologies, consumer perspectives, AHP

\section{Introduction}

Water constitutes for about $70 \%$ of the earth's geographical area while only $1 \%$ of it is potable. As per the $2^{\text {nd }} U N$ World Water Development Report (2006), more than a billion people lacked access to safe drinking water. In the developing world very few countries treat water and sanitation as a political priority, with majority countries allocating limited budget. Even with the limited budgets emphasis has been providing infrastructure for water supply, with little or no investment on water quality. The world's most serious health issues arise from unsafe and inadequate water supplies. Drinking water along with poor sanitation and hygiene contribute to 4 million cases of diarrheal diseases annually of which 1.5 million are children below 5 years (UNICEF, 2008), with 1,600 deaths daily in India. In most cases, drinking water which is available is not portable and contaminated with microbes and organisms, organic and inorganic chemical pollutants. In India, 30\% of urban and $90 \%$ of rural households still depend completely on untreated surface or groundwater (India water portal, 2009) resulting in 37.7 million people being affected and 73 million working days lost due to waterborne disease annually. As per Water Aid report (2010) the economic burden resulting due to waterborne diseases is around ` 3000 million.

The Target 7c of United Nations Millennium Development Goals is to reduce by half, the proportion of people without sustainable access to safe drinking water, by 2015 . In order to reach the goal, India has been investing in providing safe DW and sanitation to the tune of 1,105 billion from independence till the $10^{\text {th }}$ plan $(2002-2007)$. With such a high priority for provision of safe drinking water many governmental and nongovernmental agencies are involved in the business of providing safe drinking water. On the Government front, the focus has been on development of water infrastructure more so for providing drinking water to urban areas. However, as per Census 2001, only $17.9 \%$ in rural and $62.0 \%$ in urban areas have access to treated water. With most of water being untreated, and with no assurance of treated water remaining pure till it reaches households, increasing number of people are becoming conscious of the risks of drinking contaminated water and have been investing on water purifiers.

Table 1

Drinking Water Source Status as per Census 2011 in India

\begin{tabular}{|c|c|c|c|}
\hline $\begin{array}{l}\text { Type of Drinking } \\
\text { Water Source }\end{array}$ & Rural & Urban & $\begin{array}{l}\text { India } \\
\text { Average }\end{array}$ \\
\hline Tap Water & 30.8 & 70.6 & 43.5 \\
\hline Treated & 17.9 & 62.0 & 32.0 \\
\hline Untreated & 13.0 & 8.6 & 11.6 \\
\hline Well Water & 13.3 & 6.2 & 11.0 \\
\hline Covered & 1.5 & 1.7 & 1.6 \\
\hline Uncovered & 11.8 & 4.5 & 9.4 \\
\hline Hand pump / Tube well & 51.9 & 20.8 & 42.0 \\
\hline Other Sources & 4.0 & 2.5 & 3.5 \\
\hline
\end{tabular}


It has been found that household systems are more effective than centralized systems in that it ensures quality of drinking water at the point of consumption. The commercial household water purifier industry has seen a phenomenal growth, growing at the rate of $20 \%$ year and now stands at $` 15$ billion market. The motivation of the study is to find out which of the currently available household level drinking water treatment technologies are suitable for the urban and rural households.

\section{Hypotheses/Objectives}

The objective of the study is to compare the technologies in the rural and urban context by understanding the preferences so as to enable appropriate choice of technology. The scope of the study is to select technologies which are common for urban and rural context, while the preferences of urbanites and ruralites are different.

\section{Research Design/Methodology}

The steps involved in the current research are given below.

1. Identification of ten technologies was undertaken using market survey, household survey of urban and rural people. The technology alternatives selected were common for urban and rural set up, of which five technologies were conventional methods (Alum, Boiling, Alum-Boiling-Straining (Sobsey, 2002, Thomson, 2008, Verma, 2010), SODIS, Biosand Filter (Michael, 2008), Ceramic Candle Filter (Amber, 2005)), while the other five were commercially available technologies (Terafil Filter (Khuntia, 2010), Tata Swach (Tata Chemicals, 2004), Pureit (Pureitwater, 2004), Aquaguard Classic (Eurekaforbes, 2011)).

Primary data for each of the technology were obtained from discussions and interviews with Government officers and the relevant organizations, companies, officials and other key informants. The order of preferences of urban and rural people was obtained through survey on candidate technological, performing, social, economic and time factors.

2. Ranking of the technologies was carried out using Analytical Hierarchy Process (AHP); a Multi Criteria Decision Making (MCDM) tool. As AHP is a simple and easy multi-criteria decision making tool, developed by the mathematician Thomas Saaty (Saaty, 1990), is used for selection of alternatives in the current study.

\section{Data/Model Analysis}

\subsection{Perspective for AHP}

The choice of technology for drinking water treatment at household is usually done by consumers. Further, the choice made by the urban and rural consumers differ as it is based on various factors such as their socio-economic conditions, cultural conditions, local availability, technical support available, size of the family, storage facility level, subsidy, ease of usage, level of awareness, source of water, type and extent of contamination. Thus, though the perspective considered for the present study is that of the consumers, two AHP namely for the urban and rural are carried out.

\subsection{Hierarchy Decomposition of attributes}

The problem of technology alternatives in drinking water treatment at household level is hierarchically decomposed into four levels as shown in the Figure 1. In this hierarchical structure, the technology alternatives in household level drinking water treatment are considered to be characterized by five main attributes in Level 1: Performance factors, 
Economic factors, Technological factors, Social factors and Time factors under which sub groups are attributes are grouped hierarchically. The description of attributes of each level is given in Table 1. The Performance factors are characterized by ability to treat contaminants, durability and reliability of technology at level 2. Similarly at level 2 Economic factor is characterized by three sub-attributes initial cost, operational cost and maintenance cost; Time factor is characterized by the installation time, operational time and maintenance time. The Technological factors are characterized by flexibility to demand quantities, infrastructure, possibility of self maintenance, Safety, Ecofriendliness of the technology. The attribute Social Factors is characterized by Suitability to different socio-economic strata and Brand value. Certain attributes are further characterized at level 3 including ability to treat contaminants, infrastructure and safety. Ability to treat contaminants is divided into physical, chemical, biological contaminants; Infrastructure is subdivided into space requirement and requirement of specific arrangements for installations. The safety attribute is characterized by safety in handling and ability to detect failure at level 3 .

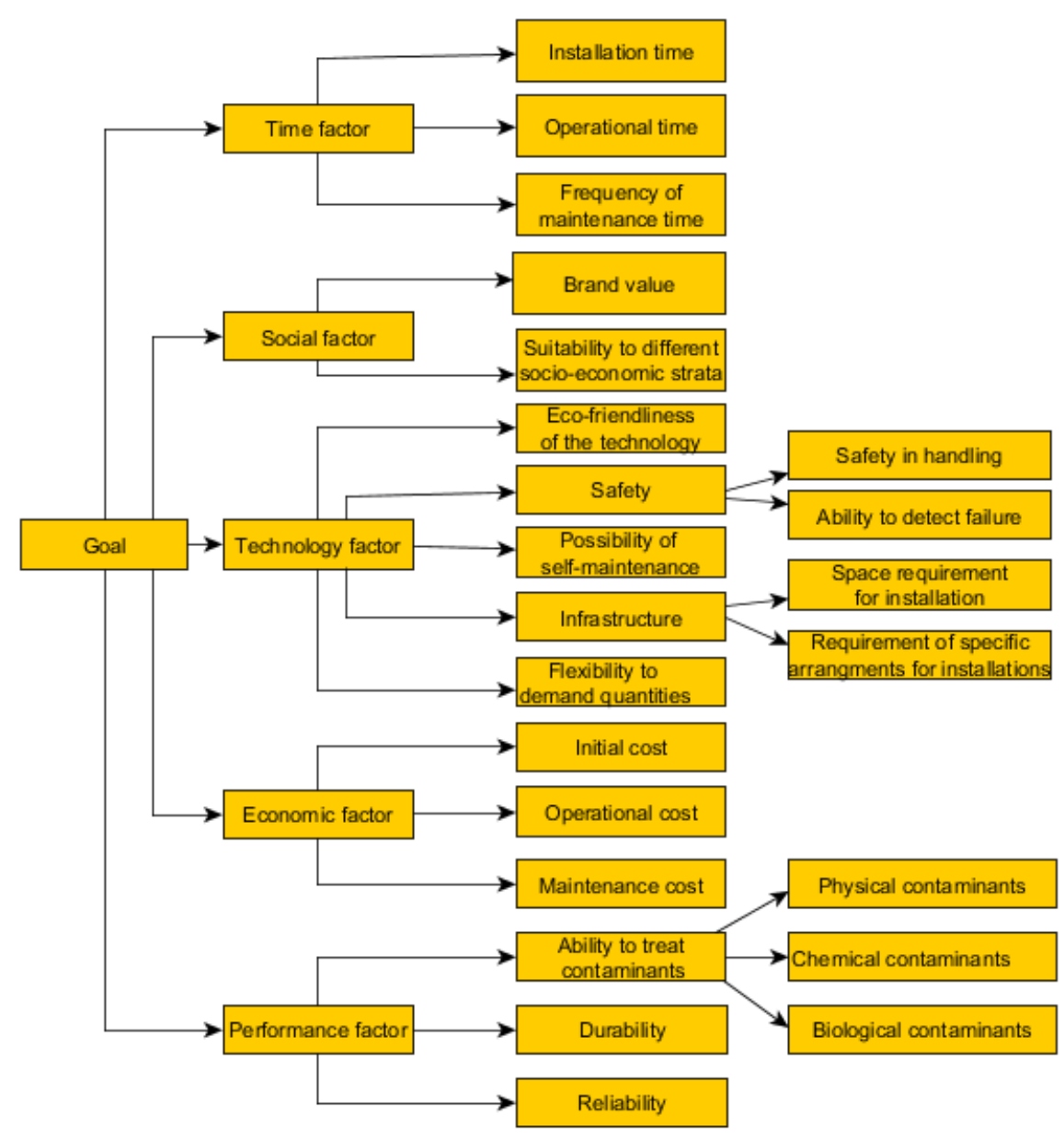

Figure 1 Hierarchic structure of criteria and sub-criteria

Table 2 
IJAHP Article: Yaparla Rao, Rao, / Comparison of Household Level Drinking Water Treatment Technologies using Analytic Hierarchy Process.

List of criterion and criteria selected for AHP

\begin{tabular}{|c|c|c|c|}
\hline $\begin{array}{l}\text { Criterion } \\
\text { Characteristics }\end{array}$ & $\begin{array}{l}\text { Crite } \\
\text { rion }\end{array}$ & Name & Description \\
\hline \multirow[t]{3}{*}{$\begin{array}{l}\text { Economic } \\
\text { Factors }\end{array}$} & $\mathrm{C} 1$ & Initial Cost & $\begin{array}{l}\text { Initial amount invested on a technology } \\
\text { usually in Rs }\end{array}$ \\
\hline & $\mathrm{C} 2$ & Operational Cost & $\begin{array}{l}\text { Amount spent in operating the drinking } \\
\text { water purifier either as electricity or fuel } \\
\text { costs. The operational cost for a complete } \\
\text { year is calculated and measured in } \\
\text { Rs/year }\end{array}$ \\
\hline & $\mathrm{C} 3$ & $\begin{array}{l}\text { Maintenance } \\
\text { Cost }\end{array}$ & $\begin{array}{l}\text { Amount spent for maintenance usually } \\
\text { measured in Rs/year }\end{array}$ \\
\hline \multirow[t]{3}{*}{ Time Factors } & $\mathrm{C} 4$ & Installation time & $\begin{array}{l}\text { Time required for installation of the } \\
\text { technology measured in minutes }\end{array}$ \\
\hline & $\mathrm{C} 5$ & Operational time & $\begin{array}{l}\text { Time taken to operated for ten liters of } \\
\text { water to be treated }\end{array}$ \\
\hline & C6 & $\begin{array}{l}\text { Frequency of } \\
\text { Maintenance } \\
\text { time }\end{array}$ & $\begin{array}{l}\text { Time interval between two maintenances } \\
\text { measured in months }\end{array}$ \\
\hline \multirow[t]{6}{*}{$\begin{array}{l}\text { Performance } \\
\text { Factors }\end{array}$} & $\mathrm{C} 7$ & $\begin{array}{l}\text { Ability to treat } \\
\text { contaminants }\end{array}$ & \\
\hline & $\mathrm{C} 7 \mathrm{a}$ & $\begin{array}{l}\text { Ability to treat } \\
\text { physical } \\
\text { contaminants }\end{array}$ & $\begin{array}{l}\text { Removal of the physical contaminants } \\
\text { present in water like turbidity, color and } \\
\text { odour }\end{array}$ \\
\hline & $\mathrm{C} 7 \mathrm{~b}$ & $\begin{array}{l}\text { Ability to treat } \\
\text { chemical } \\
\text { contaminants }\end{array}$ & $\begin{array}{l}\text { Removal of chemicals contaminants } \\
\text { present in water like organic chemical } \\
\text { and pesticides }\end{array}$ \\
\hline & $\mathrm{C} 7 \mathrm{c}$ & $\begin{array}{l}\text { Ability to treat } \\
\text { biological } \\
\text { contaminants }\end{array}$ & $\begin{array}{l}\text { Removal of biological contaminants } \\
\text { present in water like bacteria, viruses, } \\
\text { protozoa and helminths }\end{array}$ \\
\hline & $\mathrm{C} 8$ & Durability & $\begin{array}{l}\text { Determines the life of the technology } \\
\text { usually measured in years }\end{array}$ \\
\hline & C9 & Reliability & $\begin{array}{l}\text { Dependability on the technology, } \\
\text { performance assurance }\end{array}$ \\
\hline $\begin{array}{l}\text { Technological } \\
\text { factors }\end{array}$ & $\mathrm{C} 10$ & $\begin{array}{l}\text { Flexibility to } \\
\text { demand } \\
\text { Quantities }\end{array}$ & $\begin{array}{l}\text { Capacity of the technology to cater } \\
\text { different quantities/ requirements } \\
\text { depending on the size of household, the }\end{array}$ \\
\hline $\begin{array}{l}\text { International Sym } \\
\text { the Analytic Hierc } \\
\text { Process }\end{array}$ & ium of & 5 & $\begin{array}{l}\text { Washington, D. C. } \\
\text { June } 29 \text { - July 2, } 2014\end{array}$ \\
\hline
\end{tabular}




\begin{tabular}{|c|c|c|c|}
\hline \multicolumn{4}{|r|}{ rate of treatment } \\
\hline & \multicolumn{3}{|c|}{$\begin{array}{l}\text { Additional } \\
\text { infrastructure } \\
\text { Requirements }\end{array}$} \\
\hline & $\mathrm{C} 11 \mathrm{a}$ & $\begin{array}{l}\text { Space } \\
\text { requirement for } \\
\text { installation }\end{array}$ & $\begin{array}{l}\text { The additional space requirement in } \mathrm{ft}^{2} \\
\text { which consumers have to allot or invest } \\
\text { in }\end{array}$ \\
\hline & $\mathrm{C} 11 \mathrm{~b}$ & $\begin{array}{l}\text { Requirement of } \\
\text { specific } \\
\text { arrangements }\end{array}$ & $\begin{array}{l}\text { Need for specific arrangement like power } \\
\text { supply, drainage, water mount, etc }\end{array}$ \\
\hline & $\mathrm{C} 12$ & $\begin{array}{l}\text { Possibility of } \\
\text { self maintenance }\end{array}$ & $\begin{array}{l}\text { Ability to maintain the technology by } \\
\text { consumers themselves }\end{array}$ \\
\hline & $\mathrm{C} 13$ & Safety & \\
\hline & $\mathrm{C} 13 \mathrm{a}$ & $\begin{array}{l}\text { Safety in } \\
\text { handling } \\
\text { Ability to detect } \\
\text { failure }\end{array}$ & $\begin{array}{l}\text { Safety requirements for handling a } \\
\text { technology, including proper grounding } \\
\text { for electric equipments, high temperature } \\
\text { or exposure to chemicals, etc }\end{array}$ \\
\hline & $\mathrm{C} 13 \mathrm{~b}$ & $\begin{array}{l}\text { Ability to detect } \\
\text { failure }\end{array}$ & $\begin{array}{l}\text { Automatic facilities available or any sort } \\
\text { of measurement which is used to detect } \\
\text { the failure }\end{array}$ \\
\hline & C14 & $\begin{array}{l}\text { Eco-friendliness } \\
\text { of the } \\
\text { technology }\end{array}$ & $\begin{array}{l}\text { Impact of the drinking water purifier } \\
\text { technology on the environment in terms } \\
\text { of resource requirements, materials of } \\
\text { construction, disposal of the used } \\
\text { components }\end{array}$ \\
\hline \multirow[t]{2}{*}{ Social factors } & $\mathrm{C} 15$ & $\begin{array}{l}\text { Suitability to } \\
\text { different socio- } \\
\text { economic strata }\end{array}$ & $\begin{array}{l}\text { Whether piped water supply to individual } \\
\text { household is there or water is to be } \\
\text { collected from source or stand-post, } \\
\text { Whether continuous water supply is } \\
\text { there, whether water storage facilities are } \\
\text { available }\end{array}$ \\
\hline & $\mathrm{C} 16$ & Brand value & $\begin{array}{l}\text { Brand value means the technology that is } \\
\text { either developed by industries, } \\
\text { companies, etc or the one which is } \\
\text { promoted by local non-governmental } \\
\text { bodies }\end{array}$ \\
\hline
\end{tabular}

\subsection{Attribute Classification}


IJAHP Article: Yaparla Rao, Rao, / Comparison of Household Level Drinking Water Treatment Technologies using Analytic Hierarchy Process.

For AHP comparison, attributes are further classified into qualitative and quantitative. The values for each quantitative and qualitative attributes are given in the Table 3 and Table 4 respectively.

Table 3

Quantitative attributes and their values

\begin{tabular}{|c|c|c|c|c|c|c|c|c|c|c|c|}
\hline $\begin{array}{c}\text { Criterio } \\
\mathrm{n}\end{array}$ & $\mathrm{T} 1$ & $\mathrm{~T} 2$ & T3 & $\mathrm{T} 4$ & T5 & T6 & $\mathrm{T} 7$ & $\mathrm{~T} 8$ & T9 & $\mathrm{T} 10$ & $\underset{\mathrm{c}}{\mathrm{C} / \mathrm{B}}$ \\
\hline $\begin{array}{l}\mathrm{C} 1 \\
\text { (Rs) }\end{array}$ & 470 & 300 & 400 & $\begin{array}{c}100- \\
150\end{array}$ & $\begin{array}{l}600- \\
1500\end{array}$ & 500 & 450 & 1498 & 2000 & 7390 & $\mathrm{C}$ \\
\hline $\begin{array}{c}\mathrm{C} 2 \\
(\mathrm{Rs} / \mathrm{yea} \\
\mathrm{r})\end{array}$ & 170 & $\begin{array}{l}1404^{\mathrm{a}} / \\
1500^{\mathrm{b}}\end{array}$ & 1574 & Nil & Nil & Nil & Nil & Nil & Nil & 20 & $\mathrm{C}$ \\
\hline $\begin{array}{c}\mathrm{C} 3 \\
\text { (Rs/yea } \\
\text { r) }\end{array}$ & Nil & Nil & $50-75$ & 50 & Nil & 160 & 225 & 600 & 1200 & 1200 & $\mathrm{C}$ \\
\hline $\begin{array}{c}\text { C4 } \\
(\mathrm{min})\end{array}$ & 10 & 10 & 15 & 10 & 10 & 10 & 15 & 15 & 15 & 30 & $\mathrm{C}$ \\
\hline $\begin{array}{c}\text { C5 } \\
(\mathrm{min})\end{array}$ & 120 & 30 & 160 & 360 & $\begin{array}{l}180- \\
240\end{array}$ & 480 & 600 & $\begin{array}{l}150- \\
200\end{array}$ & $\begin{array}{l}66- \\
333\end{array}$ & 10 & $\mathrm{C}$ \\
\hline $\begin{array}{c}\text { C6 } \\
\text { (per } \\
\text { year) }\end{array}$ & 2 & 2 & 2 & 10 & 0 & 2 & 2 & 1 & 1 & 1 & B \\
\hline $\begin{array}{c}\text { C8 } \\
\text { (years) }\end{array}$ & $1 / 2$ & $\begin{array}{l}\text { fuel is } \\
\text { avilab } \\
\text { ility }\end{array}$ & $\begin{array}{l}\text { fuel } \\
\text { is } \\
\text { avila } \\
\text { bility } \\
\text { and } \\
\text { alum }\end{array}$ & $\begin{array}{c}\text { Prese } \\
\text { nce } \\
\text { of } \\
\text { sunli } \\
\text { ght }\end{array}$ & 30 & 3 & 6 & 5 & 5 & 10 & B \\
\hline
\end{tabular}

Note: T1: Alum, T2: Boiling, T3: Alum-Boiling-Straining (Sobsey, 2002, Thomson, 2008, Verma, 2010), T4: SODIS, T5: Biosand Filter (Michael, 2008), T6: Ceramic Candle Filter (Amber, 2005), T7: Terafil Filter (Khuntia, 2010), T8: Tata Swach (Tatachemicals, 2004), T9: Pureit (Pureitwater, 2004), T10: Aquaguard Classic (Eurekaforbes, 2011).

${ }^{a}$ Operational cost for urban areas with LPG

${ }^{\mathrm{b}}$ Operational cost considering firewood as fuel

${ }^{\mathrm{c}}$ Cost or Benefit

Table 4

Qualitative attributes and their values

International Symposium of

Washington, D. C. the Analytic Hierarchy June 29 - July 2, 2014

Process 
IJAHP Article: Yaparla Rao, Rao, / Comparison of Household Level Drinking Water Treatment Technologies using Analytic Hierarchy Process.

\begin{tabular}{lllllllllll}
\hline $\begin{array}{l}\text { Criteri } \\
\text { on }\end{array}$ & T1 & T2 & T3 & T4 & T5 & T6 & T7 & T8 & T9 & T10 \\
\hline C7a & M & L & H & L & H & H & H & H & H & V H \\
\hline C7b & M & L & M & L & M & M & M & M & M & H \\
\hline C7c & M & V H & V H & V H & H & H & H & H & H & V H \\
\hline C9 & H & H & H & L & M & L & L & L & V L & H \\
\hline C10 & H & H & H & L & M & L & L & L & L & H \\
\hline C11a & H & M & M & L & L & M & H & H & H & H \\
\hline C11b & H & L & L & H & M & H & H & H & H & H \\
\hline C12 & H & H & H & H & H & H & H & M & M & L \\
\hline C13a & M & L & L & H & M & H & H & H & H & H \\
\hline C13b & M & H & H & M & M & M & M & H & H & H \\
\hline C14 & M & L & L & H & H & H & H & M & M & M \\
\hline C15 & L & M & M & L & L & M & M & H & H & M \\
\hline C16 & L & L & L & L & L & M & M & H & H & H \\
\hline
\end{tabular}

Note: H High, M Medium, L Low, VH Very High, VL Very Low

\subsection{Criteria Weightage}

The weightages were attributed through consensus by professionals working in water treatment technologies and AHP and also from information collected from household level survey, market survey, talking to various numbers of people belonging to government and non-governmental organizations. To illustrate Table 5 shows the weightages for urban context given by the decision-makers. Similar exercise was carried out for rural context.

Table 5

Level 1 Criteria weights for Urban context

\begin{tabular}{|c|c|c|c|c|c|c|}
\hline Criterion & $\begin{array}{l}\text { Performance } \\
\text { Factors }\end{array}$ & $\begin{array}{l}\text { Econom } \\
\text { ic } \\
\text { Factors }\end{array}$ & $\begin{array}{l}\text { Technologic } \\
\text { al Factors }\end{array}$ & $\begin{array}{l}\text { Social } \\
\text { Factor } \\
\mathrm{S}\end{array}$ & $\begin{array}{l}\text { Time } \\
\text { factors }\end{array}$ & $\begin{array}{l}\text { Priority } \\
\text { Value }\end{array}$ \\
\hline $\begin{array}{l}\text { Performance } \\
\text { Factors }\end{array}$ & 1.0000 & 2.0000 & 3.0000 & $\begin{array}{l}3.000 \\
0\end{array}$ & 2.0000 & $\begin{array}{l}0.356 \\
5\end{array}$ \\
\hline Economic Factors & 0.5000 & 1.0000 & 3.0000 & 4.000 & 3.0000 & 0.302 \\
\hline $\begin{array}{l}\text { International Sympos } \\
\text { the Analytic Hierarc } \\
\text { Process }\end{array}$ & $n$ of & 8 & & & $\begin{array}{r}\text { Wash } \\
\text { June } 29-\end{array}$ & $\begin{array}{l}\text { yton, D. C } \\
\text { ly } 2,2014\end{array}$ \\
\hline
\end{tabular}




\begin{tabular}{lllllll}
\hline & & & 0 & \multicolumn{2}{l}{2} \\
\hline $\begin{array}{l}\text { Technological } \\
\text { Factors }\end{array}$ & 0.3333 & 0.3333 & 1.0000 & $\begin{array}{l}2.000 \\
0\end{array}$ & 2.0000 & $\begin{array}{l}0.144 \\
7\end{array}$ \\
\hline Social Factors & 0.3333 & 0.2500 & 0.5000 & $\begin{array}{l}1.000 \\
0\end{array}$ & 0.5000 & $\begin{array}{l}0.077 \\
1\end{array}$ \\
\hline Time factors & 0.5000 & 0.3333 & 0.5000 & $\begin{array}{l}2.000 \\
0\end{array}$ & 1.0000 & $\begin{array}{l}0.119 \\
4\end{array}$ \\
\hline Cl: 0.0582 & CR: 0.0523 & & & MEV: 5.2329 & \\
\hline
\end{tabular}

CI: Consistency Index, CR: Consistency Ratio and MEV: Maximum EigenValue

\section{Results and Discussions}

\subsection{Preferences for consumers}

The consumer's preferences for an urban and rural setup vary, as their choices differ. This has come up through, household level survey, market survey, talking to various numbers of people belonging to government and non-governmental organisations. These choices differ based on their local availability of technologies, socio-economic conditions, cultural conditions, technical support available, size of the family, storage facility level, subsidy, ease of usage, level of awareness, different source of water, different type and extent of contamination. The preferences for urban and rural are described below.

\subsection{Urban Context}

For an urban set up, though the source water may undergo municipal water treatment, it may still cause an outbreak of dangerous bacterial contaminants in tap water due to insufficient sewerage systems. Therefore people in urban areas prefer improving biological efficacy. Also, water being travelled and stored for a long period of time there are chances of leakage in pipes and materials getting deposited in it. This may result in chemical and biological contamination. So people in urban areas also prefer chemical efficacy. As there is a huge scope of delivery of services, consumers prefer the durability of technology over its reliability. Urban consumers prefer the technologies which are low cost, occupy less space and time to operate and maintain. As the average family size is small, meeting high demand quantities is not much preferred. Brand is one of the major determining factors for consumers. More preference is given to the automatic facilities and ease of operating it. The online technology is preferable where there are no power issues. Consumer, especially urban, are conscious about the disposal of the used products and their impact on environment, which is reflected by their choice of technology.

\subsection{Rural Context}

For rural areas water may be contaminated directly at the source or may get contaminated during collection, storage and use in the home. So it is necessary to treat the biological, 
physical and chemical contaminants. The ability to treat depends on the extent of contamination at each stage. Reliability of the technology is also preferred as they cannot rely completely on maintenance services. Consumers prefer low initial cost technologies, made up of locally available materials which are easy to manufacture, operate and maintenance. Maintenance cost is expected to be less, as there are less provisions of service and also the replaceable parts are not available everywhere. Consumers do not mind even if the operational time and space required for installation is large. They are not much aware about the commercial products and their brands while the technologies which are promoted or developed by government or non-governmental organizations are more popular. As the population size is high, it essential to cater different demand quantities. People are aware about the safety process for boiling however the ability to detect failure is given less importance. Preference is given to self maintained technologies. These preferences have contributed in identification of the attributes which define the required goal for the given consumers perspective.

\subsection{Ranking of Technologies}

After comparison of attributes at each level, priority values have come up based on the given situation, conditions, preferences and knowledge. It comes out to be that the initial cost is given most preference, as people preferred to have low cost technology. The ability to treat biological contaminants is preferred over chemical and physical. Durability of the technology is given the next priority as consumers want the technology to sustain for long period. Thus, the performance factors have a major role in ranking the technologies. Economic factors follow performance factors, where maintenance cost plays an important role. Urban consumers prefer less time for maintenance of technology which is one among the top priority. Thus, maintenance factors also play a major role in giving the preferences. Operational time is the next preference followed by technological factors like flexibility to demand quantities and possibility of self maintenance. Flexibility to demand quantities, ability to detect failure, brand value, eco friendliness, space requirement for installation have come out to be different from the preferences considered and expected.

Initial cost has come out to be the top priority followed by reliability and maintenance cost. Thus, economic factors contribute to a greater proportion in determining the technologies. Durability is the next attribute in the priority list, contributing performance factors. Possibility of self maintenance is given the next priority followed by flexibility to demand quantities. Ability to treat physical, chemical and biological have come to have low priority than expected. Time factors are also given least priority apart from the maintenance time, as it is essential to maintain it for long duration.

Both the rural and urban areas have similar priority given to low initial cost, maintenance cost, operational cost and self maintenance. While urban areas have higher preference in maintenance time, operational time, brand value, space requirements and eco-friendliness of the technology which is expected. Reliability is given higher preference in rural while in urban it is durability. It is slightly surprising to notice that the ability to treat the contaminants is given higher preference in urban areas compared to rural.

Table 6 
IJAHP Article: Yaparla Rao, Rao, / Comparison of Household Level Drinking Water Treatment Technologies using Analytic Hierarchy Process.

Comparison of Criteria priority values for urban and rural

\begin{tabular}{|c|c|c|c|c|c|}
\hline \multicolumn{2}{|l|}{ Criterion } & \multirow{2}{*}{$\begin{array}{l}\begin{array}{l}\text { Priority } \\
\text { Value }\end{array} \\
0.1893\end{array}$} & \multirow{2}{*}{$\begin{array}{l}\text { Urban } \\
1\end{array}$} & \multirow{2}{*}{$\begin{array}{l}\begin{array}{l}\text { Priority } \\
\text { Value }\end{array} \\
0.2603\end{array}$} & \multirow{2}{*}{$\begin{array}{l}\text { Rura } \\
1 \\
1\end{array}$} \\
\hline $\mathrm{C} 1$ & Initial Cost & & & & \\
\hline $\mathrm{C} 2$ & Operational Cost & 0.0282 & 10 & 0.0428 & 8 \\
\hline $\mathrm{C} 3$ & Maintenance Cost & 0.0845 & 4 & 0.1056 & 3 \\
\hline $\mathrm{C} 4$ & Installation time & 0.0161 & 14 & 0.0061 & 17 \\
\hline $\mathrm{C} 5$ & Operational time & 0.0335 & 8 & 0.0237 & 11 \\
\hline C6 & Frequency of Maintenance time & 0.0698 & 5 & 0.0552 & 5 \\
\hline $\mathrm{C} 7 \mathrm{a}$ & $\begin{array}{l}\text { Ability to treat physical } \\
\text { contaminants }\end{array}$ & 0.0209 & 12 & 0.0137 & 12 \\
\hline $\mathrm{C} 7 \mathrm{~b}$ & $\begin{array}{l}\text { Ability to treat chemical } \\
\text { contaminants }\end{array}$ & 0.0276 & 11 & 0.0056 & 18 \\
\hline $\mathrm{C} 7 \mathrm{c}$ & $\begin{array}{l}\text { Ability to treat biological } \\
\text { contaminants }\end{array}$ & 0.1272 & 2 & 0.0338 & 10 \\
\hline $\mathrm{C} 8$ & Durability & 0.1108 & 3 & 0.0966 & 4 \\
\hline C9 & Reliability & 0.0698 & 5 & 0.1755 & 2 \\
\hline $\mathrm{C} 10$ & Flexibility to demand Quantities & 0.0560 & 7 & 0.0457 & 7 \\
\hline C11a & Space requirement for installation & 0.0105 & 17 & 0.0079 & 16 \\
\hline $\mathrm{C} 11 \mathrm{~b}$ & $\begin{array}{l}\text { Requirement of specific } \\
\text { arrangements }\end{array}$ & 0.0015 & 18 & 0.0016 & 20 \\
\hline $\mathrm{C} 12$ & Possibility of self maintenance & 0.0333 & 9 & 0.0504 & 6 \\
\hline $\mathrm{C} 13 \mathrm{a}$ & $\begin{array}{l}\text { Safety in handling } \\
\text { Ability to detect failure }\end{array}$ & 0.0137 & 16 & 0.0053 & 19 \\
\hline $\mathrm{C} 13 \mathrm{~b}$ & Ability to detect failure & 0.0137 & 16 & 0.0107 & 14 \\
\hline $\mathrm{C} 14$ & Eco-friendliness of the technology & 0.0160 & 15 & 0.0115 & 13 \\
\hline $\mathrm{C} 15$ & $\begin{array}{l}\text { Suitability to different socio- } \\
\text { economic strata }\end{array}$ & 0.0578 & 6 & 0.0399 & 9 \\
\hline $\mathrm{C} 16$ & Brand value & 0.0192 & 13 & 0.0080 & 15 \\
\hline
\end{tabular}

\subsection{Technology Comparison for Urban and Rural context}


Boiling is coming has come out to be the top priority as its initial cost is low, its durability and reliability are high, as long as the fuel is available. Its performance is also good, as it just needs to treat the biological contaminants. These attributes have come out to be the priority factors in technology ranking. Boiling also has less maintenance time and operational time compared to some of the other technologies. Also the suitability to different socio-economic strata and flexibility to demand quantities are high. Though boiling has high operational cost with high fuel consumption as it has medium priority, it is not given that importance. Boiling has drawback of concentrating chemicals it doesn't have much impact in ranking, as municipal water has low chemical contamination. Also boiling is suggested by doctors. Aquagaurd has come out to be the second technology preference as its ability to treat biological contaminants is high, maintenance time is long, durability is also high. Also it has high flexibility to demand quantities, less operational time, low operational cost, high maintenance time. As it satisfies almost all the priorities it has been ranked second. It has been ranked second because of its very high initial cost of the aquagaurd is very high. Alum-Boiling and straining has been ranked third as its initial cost is low, with high durability, ability to treat contaminants, reliability and also low maintenance cost and time. These are few reasons the combination of the three methods have been ranked three. SODIS has come out to be fourth preference as its initial cost is very low, durability is high and ability to treat contaminants is high along with very less maintenance cost and no operational cost. While its reliability is less as it is not suitable for all seasons. The other commercial technologies like Pureit, Tata Swach, ceramic candle filter, have come to have low ranks as it does not satisfy most of the criteria required.

Table 7

Final Criterion weights and ranking of technologies for Urban context

\begin{tabular}{|c|c|c|c|c|c|c|c|c|c|c|c|}
\hline Criteria & $\begin{array}{l}\text { Weighta } \\
\text { ge }\end{array}$ & $\mathrm{T} 1$ & $\mathrm{~T} 2$ & T3 & $\mathrm{T} 4$ & $\mathrm{~T} 5$ & T6 & $\mathrm{T} 7$ & $\mathrm{~T} 8$ & T9 & $\mathrm{T} 10$ \\
\hline $\mathrm{C} 1$ & 0.189 & 0.116 & 0.225 & 0.116 & 0.292 & $\begin{array}{l}0.04 \\
1\end{array}$ & 0.058 & $\begin{array}{l}0.05 \\
8\end{array}$ & 0.039 & $\begin{array}{l}0.03 \\
1\end{array}$ & 0.025 \\
\hline $\mathrm{C} 2$ & 0.028 & 0.057 & 0.017 & 0.014 & 0.136 & $\begin{array}{l}0.13 \\
6\end{array}$ & 0.136 & $\begin{array}{l}0.13 \\
6\end{array}$ & 0.136 & $\begin{array}{l}0.13 \\
6\end{array}$ & 0.094 \\
\hline $\mathrm{C} 3$ & 0.085 & 0.183 & 0.183 & 0.092 & 0.180 & $\begin{array}{l}0.18 \\
0\end{array}$ & 0.061 & $\begin{array}{l}0.04 \\
6\end{array}$ & 0.032 & $\begin{array}{l}0.02 \\
3\end{array}$ & 0.020 \\
\hline $\mathrm{C} 4$ & 0.016 & 0.192 & 0.192 & 0.192 & 0.105 & $\begin{array}{l}0.05 \\
2\end{array}$ & 0.067 & $\begin{array}{l}0.07 \\
5\end{array}$ & 0.046 & $\begin{array}{l}0.04 \\
6\end{array}$ & 0.032 \\
\hline $\mathrm{C} 5$ & 0.034 & 0.094 & 0.172 & 0.066 & 0.037 & $\begin{array}{l}0.04 \\
4\end{array}$ & 0.027 & $\begin{array}{l}0.02 \\
1\end{array}$ & 0.085 & $\begin{array}{l}0.15 \\
1\end{array}$ & 0.304 \\
\hline C6 & 0.070 & 0.158 & 0.158 & 0.158 & 0.158 & $\begin{array}{l}0.15 \\
8\end{array}$ & 0.053 & $\begin{array}{l}0.05 \\
3\end{array}$ & 0.040 & $\begin{array}{l}0.03 \\
2\end{array}$ & 0.032 \\
\hline $\mathrm{C} 7 \mathrm{a}$ & 0.021 & 0.039 & 0.020 & 0.078 & 0.020 & 0.11 & 0.147 & 0.11 & 0.151 & 0.15 & 0.160 \\
\hline
\end{tabular}


IJAHP Article: Yaparla Rao, Rao, / Comparison of Household Level Drinking Water Treatment Technologies using Analytic Hierarchy Process.

\begin{tabular}{|c|c|c|c|c|c|c|c|c|c|c|c|}
\hline & & & & & & 7 & & 7 & & 1 & \\
\hline $\mathrm{C} 7 \mathrm{~b}$ & 0.028 & 0.064 & 0.032 & 0.032 & 0.032 & $\begin{array}{l}0.06 \\
4\end{array}$ & 0.129 & $\begin{array}{l}0.19 \\
3\end{array}$ & 0.129 & $\begin{array}{l}0.13 \\
2\end{array}$ & 0.193 \\
\hline $\mathrm{C} 7 \mathrm{c}$ & 0.127 & 0.027 & 0.135 & 0.159 & 0.108 & $\begin{array}{l}0.08 \\
1\end{array}$ & 0.081 & $\begin{array}{l}0.05 \\
4\end{array}$ & 0.108 & $\begin{array}{l}0.10 \\
8\end{array}$ & 0.138 \\
\hline $\mathrm{C} 8$ & 0.111 & 0.022 & 0.199 & 0.110 & 0.044 & $\begin{array}{l}0.17 \\
7\end{array}$ & 0.085 & $\begin{array}{l}0.08 \\
5\end{array}$ & 0.089 & $\begin{array}{l}0.08 \\
9\end{array}$ & 0.100 \\
\hline C9 & 0.070 & 0.093 & 0.093 & 0.185 & 0.031 & $\begin{array}{l}0.01 \\
9\end{array}$ & 0.185 & $\begin{array}{l}0.04 \\
6\end{array}$ & 0.046 & $\begin{array}{l}0.03 \\
2\end{array}$ & 0.271 \\
\hline $\mathrm{C} 10$ & 0.056 & 0.169 & 0.087 & 0.087 & 0.037 & $\begin{array}{l}0.04 \\
5\end{array}$ & 0.037 & $\begin{array}{l}0.03 \\
7\end{array}$ & 0.037 & $\begin{array}{l}0.03 \\
7\end{array}$ & 0.429 \\
\hline C11a & 0.011 & 0.059 & 0.059 & 0.032 & 0.169 & $\begin{array}{l}0.02 \\
9\end{array}$ & 0.110 & $\begin{array}{l}0.11 \\
0\end{array}$ & 0.157 & $\begin{array}{l}0.15 \\
7\end{array}$ & 0.121 \\
\hline $\mathrm{C} 11 \mathrm{~b}$ & 0.002 & 0.095 & 0.047 & 0.047 & 0.032 & $\begin{array}{l}0.03 \\
2\end{array}$ & 0.182 & $\begin{array}{l}0.18 \\
2\end{array}$ & 0.182 & $\begin{array}{l}0.18 \\
2\end{array}$ & 0.019 \\
\hline C12 & 0.033 & 0.153 & 0.153 & 0.153 & 0.153 & $\begin{array}{l}0.05 \\
1\end{array}$ & 0.150 & $\begin{array}{l}0.07 \\
6\end{array}$ & 0.051 & $\begin{array}{l}0.04 \\
1\end{array}$ & 0.021 \\
\hline C13a & 0.014 & 0.117 & 0.024 & 0.020 & 0.218 & $\begin{array}{l}0.03 \\
9\end{array}$ & 0.117 & $\begin{array}{l}0.11 \\
7\end{array}$ & 0.117 & $\begin{array}{l}0.11 \\
7\end{array}$ & 0.117 \\
\hline $\mathrm{C} 13 \mathrm{~b}$ & 0.014 & 0.037 & 0.037 & 0.037 & 0.021 & $\begin{array}{l}0.07 \\
4\end{array}$ & 0.111 & $\begin{array}{l}0.11 \\
1\end{array}$ & 0.179 & $\begin{array}{l}0.17 \\
9\end{array}$ & 0.212 \\
\hline C14 & 0.016 & 0.144 & 0.030 & 0.030 & 0.048 & $\begin{array}{l}0.28 \\
2\end{array}$ & 0.072 & $\begin{array}{l}0.27 \\
6\end{array}$ & 0.048 & $\begin{array}{l}0.03 \\
6\end{array}$ & 0.036 \\
\hline C15 & 0.058 & 0.072 & 0.216 & 0.216 & 0.026 & $\begin{array}{l}0.03 \\
8\end{array}$ & 0.037 & $\begin{array}{l}0.03 \\
7\end{array}$ & 0.037 & $\begin{array}{l}0.03 \\
7\end{array}$ & 0.283 \\
\hline \multirow[t]{3}{*}{$\mathrm{C} 16$} & 0.019 & 0.039 & 0.070 & 0.027 & 0.021 & $\begin{array}{l}0.01 \\
6\end{array}$ & 0.142 & $\begin{array}{l}0.10 \\
6\end{array}$ & 0.191 & $\begin{array}{l}0.16 \\
8\end{array}$ & 0.221 \\
\hline & & 0.096 & 0.151 & 0.119 & 0.125 & $\begin{array}{l}0.08 \\
9\end{array}$ & 0.083 & $\begin{array}{l}0.06 \\
9\end{array}$ & 0.070 & $\begin{array}{l}0.06 \\
8\end{array}$ & 0.130 \\
\hline & Rank & 5 & 1 & 4 & 3 & 6 & 7 & 8 & 9 & 10 & 2 \\
\hline
\end{tabular}

SODIS has been ranked top most for rural as it has low initial cost and less maintenance cost, high durability, suitability to different economic strata, flexibility to demand quantities. and maintenance time. These are some of the reasons for SODIS being ranked top. It has low reliability as it cannot be used in all seasons. Boiling has come out to be second rank as it satisfies all the required criteria, apart from its high operational cost and International Symposium of the Analytic Hierarchy 13 Process

Washington, D. C. June 29 - July 2, 2014 
lack of eco-friendliness. Other reasons are similar to that described in the above. Biosand filter is ranked third while it has almost most favorable factors to be implemented in rural context. Its initial cost is medium, reliability and maintenance time being high with no operational and maintenance cost. It is made up of local materials so there is a great chance of self maintenance and thus no market facilities required. The major disadvantage is it doesn't have capacity to different demand quantities and also its low adaptability to different socio-economic strata. Fourth preference is the combination of the technologies, that is has almost criteria satisfying. Similar to urban, commercial products have been ranked least priority as they doesn't satisfy most of the criteria's, especially due to its low market facilities

Table 8

Final Criterion weights and ranking of technologies for Rural context

\begin{tabular}{|c|c|c|c|c|c|c|c|c|c|c|c|}
\hline Criterion & Weightage & $\mathrm{T} 1$ & $\mathrm{~T} 2$ & $\mathrm{~T} 3$ & $\mathrm{~T} 4$ & $\mathrm{~T} 5$ & T6 & $\mathrm{T} 7$ & $\mathrm{~T} 8$ & T9 & $\mathrm{T} 10$ \\
\hline $\mathrm{C} 1$ & 0.260 & 0.119 & 0.219 & 0.059 & 0.363 & 0.059 & 0.059 & $\begin{array}{l}0.04 \\
1\end{array}$ & $\begin{array}{l}0.03 \\
2\end{array}$ & 0.027 & 0.021 \\
\hline $\mathrm{C} 2$ & 0.043 & 0.083 & 0.016 & 0.014 & 0.141 & 0.141 & 0.141 & $\begin{array}{l}0.14 \\
1\end{array}$ & $\begin{array}{l}0.14 \\
1\end{array}$ & 0.141 & 0.041 \\
\hline $\mathrm{C} 3$ & 0.106 & 0.165 & 0.165 & 0.165 & 0.165 & 0.165 & 0.067 & $\begin{array}{l}0.04 \\
1\end{array}$ & $\begin{array}{l}0.03 \\
5\end{array}$ & 0.018 & 0.016 \\
\hline $\mathrm{C} 4$ & 0.006 & 0.164 & 0.164 & 0.164 & 0.164 & 0.082 & 0.082 & $\begin{array}{l}0.08 \\
2\end{array}$ & $\begin{array}{l}0.04 \\
4\end{array}$ & 0.036 & 0.021 \\
\hline C5 & 0.024 & 0.094 & 0.172 & 0.066 & 0.037 & 0.044 & 0.027 & $\begin{array}{l}0.02 \\
1\end{array}$ & $\begin{array}{l}0.08 \\
5\end{array}$ & 0.151 & 0.304 \\
\hline C6 & 0.055 & 0.182 & 0.182 & 0.182 & 0.182 & 0.091 & 0.045 & $\begin{array}{l}0.04 \\
5\end{array}$ & $\begin{array}{l}0.03 \\
4\end{array}$ & 0.034 & 0.022 \\
\hline $\mathrm{C} 7 \mathrm{a}$ & 0.097 & 0.037 & 0.221 & 0.163 & 0.140 & 0.238 & 0.035 & $\begin{array}{l}0.03 \\
5\end{array}$ & $\begin{array}{l}0.02 \\
3\end{array}$ & 0.018 & 0.091 \\
\hline $\mathrm{C} 7 \mathrm{~b}$ & 0.014 & 0.037 & 0.221 & 0.163 & 0.140 & 0.238 & 0.035 & $\begin{array}{l}0.03 \\
5\end{array}$ & $\begin{array}{l}0.02 \\
3\end{array}$ & 0.018 & 0.091 \\
\hline $\mathrm{C} 7 \mathrm{c}$ & 0.006 & 0.064 & 0.032 & 0.032 & 0.032 & 0.064 & 0.129 & $\begin{array}{l}0.19 \\
3\end{array}$ & $\begin{array}{l}0.12 \\
9\end{array}$ & 0.132 & 0.193 \\
\hline $\mathrm{C} 8$ & 0.034 & 0.027 & 0.135 & 0.159 & 0.108 & 0.081 & 0.081 & $\begin{array}{l}0.05 \\
4\end{array}$ & $\begin{array}{l}0.10 \\
8\end{array}$ & 0.108 & 0.138 \\
\hline C9 & 0.175 & 0.097 & 0.221 & 0.173 & 0.029 & 0.308 & 0.050 & $\begin{array}{l}0.05 \\
0\end{array}$ & $\begin{array}{l}0.02 \\
9\end{array}$ & 0.024 & 0.021 \\
\hline $\mathrm{C} 10$ & 0.046 & 0.136 & 0.068 & 0.091 & 0.068 & 0.069 & 0.047 & $\begin{array}{l}0.06 \\
8\end{array}$ & $\begin{array}{l}0.04 \\
7\end{array}$ & 0.047 & 0.359 \\
\hline
\end{tabular}


IJAHP Article: Yaparla Rao, Rao, / Comparison of Household Level Drinking Water Treatment Technologies using Analytic Hierarchy Process.

\begin{tabular}{|c|c|c|c|c|c|c|c|c|c|c|c|}
\hline C11a & 0.002 & 0.095 & 0.047 & 0.047 & 0.032 & 0.032 & 0.182 & $\begin{array}{l}0.18 \\
2\end{array}$ & $\begin{array}{l}0.18 \\
2\end{array}$ & 0.182 & 0.019 \\
\hline $\mathrm{C} 11 \mathrm{~b}$ & 0.050 & 0.184 & 0.092 & 0.074 & 0.326 & 0.115 & 0.061 & $\begin{array}{l}0.06 \\
1\end{array}$ & $\begin{array}{l}0.03 \\
6\end{array}$ & 0.030 & 0.021 \\
\hline $\mathrm{C} 12$ & 0.005 & 0.120 & 0.042 & 0.034 & 0.308 & 0.223 & 0.061 & $\begin{array}{l}0.06 \\
1\end{array}$ & $\begin{array}{l}0.06 \\
1\end{array}$ & 0.060 & 0.030 \\
\hline $\mathrm{C} 13 \mathrm{a}$ & 0.011 & 0.037 & 0.037 & 0.037 & 0.021 & 0.074 & 0.111 & $\begin{array}{l}0.11 \\
1\end{array}$ & $\begin{array}{l}0.17 \\
9\end{array}$ & 0.179 & 0.212 \\
\hline $\mathrm{C} 13 \mathrm{~b}$ & 0.012 & 0.074 & 0.040 & 0.049 & 0.179 & 0.274 & 0.128 & $\begin{array}{l}0.16 \\
7\end{array}$ & $\begin{array}{l}0.03 \\
4\end{array}$ & 0.027 & 0.030 \\
\hline $\mathrm{C} 14$ & 0.040 & 0.159 & 0.079 & 0.159 & 0.301 & 0.079 & 0.053 & $\begin{array}{l}0.05 \\
3\end{array}$ & $\begin{array}{l}0.05 \\
3\end{array}$ & 0.040 & 0.024 \\
\hline $\mathrm{C} 15$ & 0.008 & 0.086 & 0.043 & 0.057 & 0.166 & 0.230 & 0.160 & $\begin{array}{l}0.16 \\
3\end{array}$ & $\begin{array}{l}0.04 \\
4\end{array}$ & 0.031 & 0.021 \\
\hline \multirow[t]{3}{*}{$\mathrm{C} 16$} & 0.008 & 0.064 & 0.064 & 0.034 & 0.296 & 0.121 & 0.128 & $\begin{array}{l}0.12 \\
8\end{array}$ & $\begin{array}{l}0.06 \\
4\end{array}$ & 0.064 & 0.036 \\
\hline & & 0.113 & 0.171 & 0.116 & 0.193 & 0.149 & 0.061 & $\begin{array}{l}0.05 \\
5\end{array}$ & $\begin{array}{l}0.04 \\
4\end{array}$ & 0.040 & 0.058 \\
\hline & Rank & 5 & 2 & 4 & 1 & 3 & 6 & 8 & 9 & 10 & 7 \\
\hline
\end{tabular}

From the above tables the choice of technologies are different for an urban and rural setup. For the top rankings, technology preferences have come out to be different for urban and rural. The last rankings are almost similar for both urban and rural.

\subsection{Sensitivity Analysis}

Sensitivity analysis was carried out to study how the rankings change with removal of different attributes. In urban context, the lower-order rankings are not much sensitive to the removal of a initial cost while, the highest ranking is found to be dependent of the removal of initial cost. Thus, Aquagaurd was given a higher rank when initial cost was not considered. Apart from that there was not much difference in other rankings with SODIS falling down to $7^{\text {th }}$ rank from that of $4^{\text {th }}$. The technologies are not sensitive to other attributes. Even in rural areas initial cost is the most sensitive attribute with Biosand filters coming out to be the top preference without considering initial cost.

\section{Conclusions}

DW quality is one of the major issues of concern in the current scenario, both in urban and rural areas. Household level treatment technologies are one of the solutions for water quality. There are number of technologies available for treating DW based on the source, type and extent of contamination. For the present study, technological classification based on the conventional and commercial methods is considered. The conventional 
technologies selected for the study include alum, boiling, alum-boiling-straining, ceramic candle filter, Biosand filter while commercial technologies include SODIS, Terafil filters, Pureit, Tata Swach and Eureka Forbes Aquaguard Compact.

The preferences for selection of the technologies are based on a set of performance factors, economic factors, technological factors, social factors and time factors.

Based on the local conditions and preferences, the ranking of technologies are different for urban and rural areas. The technology comparison is performed using Analytical Hierarchical Process. For an urban setup, boiling has emerged as the most preferred choice followed by Aquagaurd, SODIS, Alum-boiling-straining and Alum. While for a rural setup, the preferred choices are SODIS, boiling, bio-sand filters, Alum-boilingstraining and Alum. The attributes for these rankings for an urban context are initial cost, ability to treat the biological contaminants and durability while for rural it is initial cost, reliability and maintenance cost. In both the cases, the technologies are sensitive to initial cost, as it plays a decisive role in ranking. Excluding the initial cost, Aquaguard in urban areas and Biosand filter in rural areas were given top ranking. The various preferences suggest the following:

- People prefer simple low cost technologies in both urban and rural areas

- Hassle free and effective product like Aquaguard is preferred in urban area, but factors like initial cost, lack of service network, need for continuous water supply \& electricity makes it less preferred in rural areas.

- In rural setup, Bio-sand filter with proper training can be a good choice. However the same is less preferred in urban setup due space requirement and social factors.

\section{Key References}

Amber, F. (2005). A Performance Study Of Ceramic Candle Filters In Kenya Including Tests For Coliphage Removal. Chapel Hilll: MIT.

D. Sobsey, M. (2002). Managing Water in the Home: Accelerated Health Gains from Improved Water Supply. North Carolina: WHO.

Eurekaforbes. (2011). Eurekaforbes. Retrieved 2011, from http://www.eurekaforbes.com: http://www.eurekaforbes.com/water-purifiers/aquaguard-compact.aspx

Khuntia, S. (2010). Terafil filters. Bhubaneshwar: IMMT.

Michael, L. (2008). Biological Sand Filters: Low-Cost Bioremediation Technique for Production. Wiley Interscience, 1-28.

Path Safe Water project. (2008). Commercial Approaches To Providing Safe Water In India: A Literature Review. Path.

Pureitwater. (2004). Pureitwater. Retrieved 2011, from http://www.pureitwater.co: http://www.pureitwater.com/IN/pureit-technology

Raju.U, S., Rangaraj.N, \& Date, A. (1995). The Influence of Development Perspectives. Elsevier Science, 27-43. 
IJAHP Article: Yaparla Rao, Rao, / Comparison of Household Level Drinking Water Treatment Technologies using Analytic Hierarchy Process.

Saaty, T.L. (1990). How to make a decision: The Analytic Hierarchy Process. European Journal of Operational Research, 48, 9-26.

Tatachemicals. (2004). Tatachemicals. Retrieved 2011, from http://www.tatachemicals.com: http://www.tatachemicals.com/products/tata_swach.htm

Thomson, P. (2008). Household Water Treatment:A summary of methods and techniques. In Safe and Sustainable Clean Water Access (pp. 73-88).

Verma, N. K., Basu, D., \& Sengupta, B. (2010). Status Of Water Treatment Plants In India. CPCB. 


\section{Appendices}

Figure depicting various technologies used

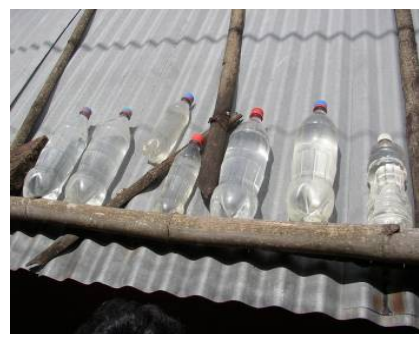

SODIS UNICEF

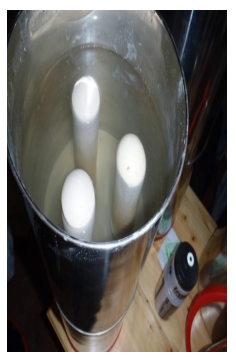

Ceramic filter (local brand)

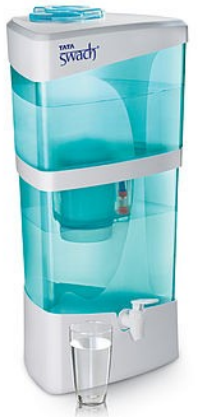

Tata Swach from Tata Chemicals

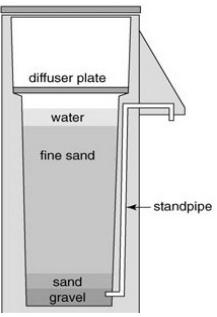

Biosand filter from CAWST, Canada

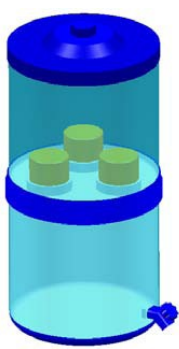

Terafil filter from CSIR-IMMT

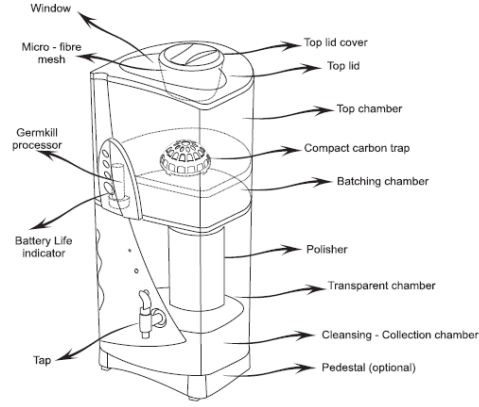

Pureit from Hindustan Unilever
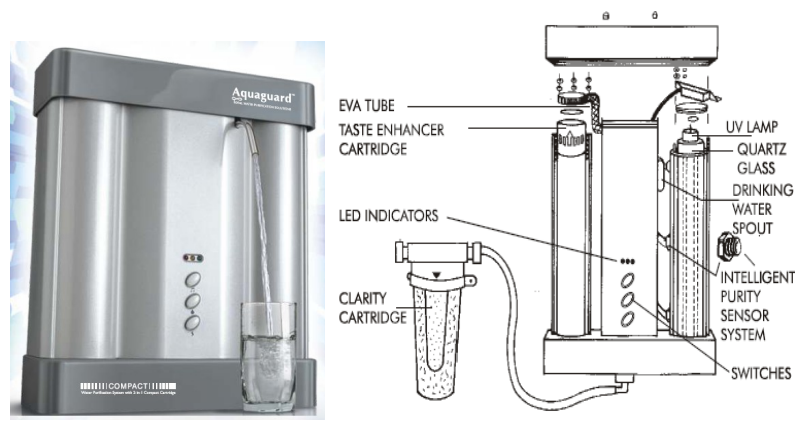

Aquagaurd from Eureka Forbes 